\title{
The Swedish Medical Products Agency's rules of procedure
}

\author{
Catarina Andersson Forsman(1)
}

The Swedish Medical Products Agency (MPA) is the Swedish national authority responsible for regulation and surveillance of the development, manufacturing and marketing of medicinal products. Relenza, a neuraminidase inhibitor used in the treatment of influenza, has been evaluated by both the Swedish MPA and the United States Food and Drug Administration.

In a paper by Mulinari et al. [1], the divergent conclusions reached by the authorities are discussed. The purpose of this letter is not to discuss the conclusions drawn by Mulinari et al. [1], but to comment on the way they refer to an assessor at the MPA. By naming a specific assessor at the MPA, the reader is given the false impression that a single employee is solely responsible for the benefit-risk evaluation of a drug. We want to emphasize that all assessments at the MPA are the work of a team of assessors with complementary competencies, including a comprehensive standardized quality assessment procedure for each decision. Hence, it is the MPA, as a national regulatory agency, that is responsible for any opinion or decision. Besides giving a misleading description of regulatory procedures, the publication of an individual assessor's name adds no scientific value to the paper and could therefore have been omitted.

\section{Author's contributions}

CAF wrote the manuscript. The author read and approved the final manuscript.

Ethics approval and consent to participate

Not applicable.

\section{Consent for publication}

Not applicable.

\section{Competing interests}

The author declares that she has no competing interests.

\section{Publisher's Note}

Springer Nature remains neutral with regard to jurisdictional claims in published maps and institutional affiliations.

Correspondence: catarina.andersson.forsman@lakemedelsverket.se

Swedish Medical Products Agency, SE -751 03 Uppsala, Sweden
Received: 29 June 2018 Accepted: 18 September 2018

Published online: 15 November 2018

\section{Reference}

1. Mulinari S, Davis C. Why European and United States drug regulators are not speaking with one voice on anti-influenza drugs: regulatory review methodologies and the importance of 'deep' product reviews. Health Res Policy Syst. 2017;15:93. https://doi.org/10.1186/s12961-017-0259-8.
Ready to submit your research? Choose BMC and benefit from:

- fast, convenient online submission

- thorough peer review by experienced researchers in your field

- rapid publication on acceptance

- support for research data, including large and complex data types

- gold Open Access which fosters wider collaboration and increased citations

- maximum visibility for your research: over 100M website views per year

At BMC, research is always in progress.

Learn more biomedcentral.com/submissions

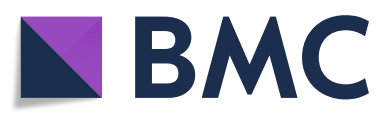

(อ) The Author(s). 2018 Open Access This article is distributed under the terms of the Creative Commons Attribution 4.0 International License (http://creativecommons.org/licenses/by/4.0/), which permits unrestricted use, distribution, and reproduction in any medium, provided you give appropriate credit to the original author(s) and the source, provide a link to the Creative Commons license, and indicate if changes were made. The Creative Commons Public Domain Dedication waiver (http://creativecommons.org/publicdomain/zero/1.0/) applies to the data made available in this article, unless otherwise stated. 